\title{
Biogeochemical processes accounting for the natural mercury variations in the Southern Ocean diatom ooze sediments
}

\author{
Sara Zaferani and Harald Biester \\ Institut für Geoökologie, AG Umweltgeochemie, Technische Universität Braunschweig, 38106 Braunschweig, Germany
}

Correspondence: Sara Zaferani (s.zaferani@tu-braunschweig.de)

Received: 22 December 2019 - Discussion started: 15 January 2020

Revised: 30 April 2020 - Accepted: 9 May 2020 - Published: 19 June 2020

\begin{abstract}
Due to its toxic nature and its high potential for biomagnification, mercury is a pollutant of concern. Understanding the marine biogeochemical cycle of mercury is crucial as consumption of mercury-enriched marine fish is the most important pathway of human exposure to monomethylmercury, a neurotoxin. However, due to the lack of long-term marine records, the role of the oceans in the global mercury cycle is poorly understood. We do not have well-documented data of natural mercury accumulations during changing environmental conditions, e.g., sea surface conditions in the ocean. To understand the influence of different sea surface conditions (climate-induced changes in ice coverage and biological production) on natural mercury accumulation, we used a continuous $\sim 170 \mathrm{~m}$ Holocene biogenic sedimentary record from Adélie Basin, East Antarctica, which mainly consists of silica-based skeletons of diatoms. We performed principal component analysis and regression analysis on element concentrations and corresponding residuals, respectively, to investigate the link between sediment mercury accumulation, terrestrial inputs, and phytoplankton productivity. Preindustrial mercury in the remote marine basin shows extremely high accumulation rates (median: $556 \mu \mathrm{g} \mathrm{m}^{-2} \mathrm{yr}^{-1}$ ) that displayed periodic-like variations. Our analyses show that the variations in total mercury concentrations and accumulation rates are associated with biological production and related scavenging of water-phase mercury by rapidly sinking algae or algae-derived organic matter after intense algae blooms. High accumulation rates of other major and trace elements further reveal that, in regions of high primary productivity, settling of biogenic materials removes a large fraction of dissolved or particulatebound elements from the free water phase through scavenging or biological uptake. The link between mercury cycling
\end{abstract}

and primary production will need to be considered in future studies of the marine mercury cycle under primary production enhancement through climatic, temperature, and nutrient availability changes.

\section{Introduction}

Mercury $(\mathrm{Hg})$ is a metal of environmental concern due to its ability to be transported through the atmosphere from industrial point sources to remote regions and its transformations into highly bioaccumulative and neurotoxic methylated forms. In the global biogeochemical cycle of $\mathrm{Hg}$, the ocean, as the dominant physical feature of our planet Earth, is of specific concern. A substantial amount of $\mathrm{Hg}(\sim 80 \%)$ which is emitted to the atmosphere from natural and anthropogenic sources reaches the ocean (Horowitz et al., 2017; Schartup et al., 2019), and ocean sediments are considered to be the ultimate sink of $\mathrm{Hg}$ on a timescale of tens of thousands of years (Fitzgerald et al., 2007; Selin, 2009; Amos et al., 2013). Despite the important role of marine sedimentation in the global $\mathrm{Hg}$ biogeochemical cycle, little is known about the rates or amount of $\mathrm{Hg}$ accumulation in marine sediments, especially in the open ocean. In contrast to the well-studied $\mathrm{Hg}$ cycling in terrestrial environments, knowledge about the temporal and spatial distribution of $\mathrm{Hg}$ in the marine environment is limited to model estimations (Mason and Sheu, 2002; Sunderland and Mason, 2007), water column measurements (Cossa et al., 2011; Lamborg et al., 2014b; Canário et al., 2017), and very few sediment measurements (Kita et al., 2013; Aksentov and Sattarova, 2020). A main reason for our limited understanding of the fate of $\mathrm{Hg}$ in the oceans is 
the lack of high-resolution marine sedimentary records, especially from the deep ocean (Zaferani et al., 2018).

$\mathrm{Hg}$ input to the ocean is primarily through atmospheric deposition (Mason et al., 1994; Driscoll et al., 2013). After deposition, as either mercuric ion $\left(\mathrm{Hg}^{2+}\right)$ or elemental $\mathrm{Hg}$ $\left(\mathrm{Hg}^{0}\right)$, $\mathrm{Hg}$ can be reduced to $\mathrm{Hg}^{0}$ and evaded to the atmosphere or scavenged from the water column by particulate matter and eventually buried in deep-sea sediments (Mason et al., 2012; Lamborg et al., 2014a). Most marine surface waters are believed to be close to equilibrium between $\mathrm{Hg}$ deposition and evasion or saturated in $\mathrm{Hg}^{0}$ due to biologically mediated (Mason et al., 1995; Rolfhus and Fitzgerald, 2004; Whalin et al., 2007) and photochemical reduction (Amyot et al., 1997; Mason et al., 2001) followed by re-emission of $\mathrm{Hg}^{0}$ to the atmosphere. It has been estimated that almost $96 \%$ of the deposited $\mathrm{Hg}$ to the ocean is lost through evasion from the surface, and only $30 \%$ of the $\mathrm{Hg}$ flux that reaches the deep ocean is preserved in sediments (Mason and Sheu, 2002). However, other studies indicate that the ocean surface waters become a sink for atmospheric $\mathrm{Hg}$ at the high nutrient levels and related high primary productivity (Soerensen et al., 2016).

There are contradictory statements about the $\mathrm{Hg}$ deposition and evasion to/from different surface waters. Early works suggest that $\mathrm{Hg}$ evasion is high in productive upwelling regions of the ocean due to enhanced biological reduction (Fitzgerald et al., 1984; Mason and Fitzgerald, 1993). More recent studies, with higher spatial and temporal resolutions, suggest lower $\mathrm{Hg}$ evasion in productive regions (O'Driscoll et al., 2006; Qureshi et al., 2010; Soerensen et al., 2013, 2014). Measurements of $\mathrm{Hg}$ from these recent studies show relatively low concentrations of atmospheric and surface water-phase $\mathrm{Hg}^{0}$ in regions with high productivity compared to areas with lower productivity. These studies related their observation to sorption and scavenging of $\mathrm{Hg}$ by suspended organic particles. They suggested that removal of $\mathrm{Hg}^{2+}$ associated with sorption and scavenging by suspended organic particles in productive regions reduces the amount of available $\mathrm{Hg}^{2+}$ for reduction and re-emission. Therefore applying the model estimates across the entire ocean introduces substantial uncertainty, and one area in particular that highlights this uncertainty is the underestimation of the role of biological productivity as a major vector of $\mathrm{Hg}$ sedimentation in the oceans.

The marine biogeochemical cycle, especially sedimentation of many elements (Fowler and Knauer, 1986; Morel and Price, 2003; Schlesinger and Bernhardt, 2013), including Hg (Kita et al., 2013; Lamborg et al., 2016; Zaferani et al., 2018), in the ocean is controlled directly and indirectly by biological productivity. Biogenic particles control the distribution of elements through primary production, sinking, and decomposition (Fowler and Knauer, 1986). Besides direct uptake across cell membranes through active metabolism, phytoplankton and sinking biogenic particles can scavenge and remove many other elements from the dissolved phase and transport them to the deep sea. Sinking speed of biogenic particles plays an important role in the final fate of those elements. Rapidly sinking particles such as diatom agglomerates transfer elements to the deep sea (Fowler and Knauer, 1986; Smetacek et al., 2012), whereas elements associated with the slowly sinking particulates will release back to the water phase through remineralization (Fowler and Knauer, 1986). In areas where pronounced seasonal blooms take place, phytoplankton species appear to reach the deep-sea floor relatively fast and intact. Seasonal blooms in the surface waters will also cause temporally variable fluxes of elements in the deep ocean (Fowler and Knauer, 1986; Michel et al., 2002; Pilskaln et al., 2004). For Hg, these findings are supported by water column (Lamborg et al., 2014b) and marine sediment measurements (Kita et al., 2013; Aksentov and Sattarova, 2020). Lamborg et al. (2014b) described a nutrientlike distribution of $\mathrm{Hg}$ in the water column of oceans. This study indicates that, similar to carbon (C) and phosphorus (P), Hg shows higher concentrations in the deep water due to its release during organic matter decomposition. Kita et al. (2013) found a positive correlation between $\mathrm{Hg}$ and the absolute abundance of phytoplankton species in sediments of the Caribbean Sea. $\mathrm{Hg}$ in these sediments was assumed to be a result of $\mathrm{Hg}$ binding by phytoplankton depositing Hg-bearing organic matter in the photic zone. A similar conclusion was reached by Aksentov and Sattarova (2020), who used a thermoscanning technique to detect $\mathrm{Hg}$ forms. They found that biological productivity controlled the $\mathrm{Hg}$ burial in northwestern Pacific bottom sediments and that the forms of $\mathrm{Hg}$ depended on the diatom content.

These observations can be due to $\mathrm{Hg}$-phytoplankton interactions and uptake or binding of $\mathrm{Hg}$ from the water by phytoplankton (Le Faucheur et al., 2014; Mason et al., 1996). This interaction controls the flux of $\mathrm{Hg}$ from the water column to sediments and facilitates the downward flux of $\mathrm{Hg}$ to the seafloor (Soerensen et al., 2014, 2016; Lamborg et al., 2016; Zaferani et al., 2018), which, as mentioned, has traditionally been considered to be slow in its nature. Thus, underestimating the role of biological productivity in the marine biogeochemical cycle of $\mathrm{Hg}$ may lead to an overestimation of reemission fluxes from surface water and an underestimation of the $\mathrm{Hg}$ flux to deep-sea sediments.

In this context, the Southern Ocean is of particular interest due to its high concentrations of nutrients and related elevated primary productivity (Arrigo et al., 1998). In the Southern Ocean, diatoms are major primary producers (Crosta et al., 2005). Their siliceous cell walls preserve well in sediments and form diatom ooze (Fütterer, 2006). The sedimentation rate of diatom ooze is high, estimated to reach up to $2 \mathrm{~cm} \mathrm{yr}^{-1}$ (Escutia et al., 2011), making diatom ooze deposits around Antarctica a unique geochemical archive to study the influence of primary productivity as well as natural and anthropogenic changes on the marine biogeochemical cycle of $\mathrm{Hg}$. 
Despite providing a unique geochemical archive, studies on $\mathrm{Hg}$ cycling in the Southern Ocean, particularly in the Antarctic region, are generally limited to water column (Cossa et al., 2011; Nerentorp Mastromonaco et al., 2017b; Canário et al., 2017), surface water/air (Nerentorp Mastromonaco et al., 2017a; Wang et al., 2017), and ice core analyses (Vandal et al., 1993). Cossa et al. (2011) showed a nutrient-like distribution of $\mathrm{Hg}$ in the water column that ranged between 0.6 and $2.8 \mathrm{pmol} \mathrm{L}^{-1}$. Nerentorp Mastromonaco et al. (2017b) found higher total $\mathrm{Hg}$ concentration than Cossa et al. (2011), with no significant vertical variations. Both studies reported seasonal variations in $\mathrm{Hg}$ concentrations and related them to seasonal variations of atmospheric $\mathrm{Hg}$ deposition (Cossa et al., 2011; Nerentorp Mastromonaco et al., 2017b) as well as the $\mathrm{Hg}$ inputs from melting sea ice and snow (Nerentorp Mastromonaco et al., 2017b). Total Hg concentrations in the Atlantic sector of the Southern Ocean obtained during a study by Canário et al. (2017) were also, in general, comparable to those obtained by Cossa et al. (2011) except for some stations that showed higher total Hg concentrations. Canário et al. (2017) attributed these differences to the different stages of phytoplankton bloom during the sampling. This led to lower dissolved $\mathrm{Hg}$ in water in the middle-end stage of the bloom compared to the beginning stage of the bloom, owing to the Hg uptake by phytoplankton (Canário et al., 2017). Measurements of gaseous elemental mercury (GEM) and dissolved gaseous mercury (DGM) in surface water showed spatial and seasonal variations as well (Nerentorp Mastromonaco et al., 2017a; Wang et al., 2017). These studies related the increase in DGM and GEM concentrations to the presence and absence of sea ice. Sea ice that could prevent $\mathrm{Hg}$ evasion to the atmosphere could initially lead to an increase in $\mathrm{Hg}$ emissions to the atmosphere when diminishing. Hg concentrations in an ice core covering the past $34 \mathrm{kyr}$ varied between 0.0005 and $0.0021 \mu \mathrm{g} \mathrm{kg}^{-1}$, corresponding to depositional fluxes of 0.009 and $0.031 \mu \mathrm{g} \mathrm{m}^{-2} \mathrm{yr}^{-1}$ during the Holocene and the Last Glacial Maximum, respectively (Vandal et al., 1993). Vandal et al. (1993) attributed the observed enhanced $\mathrm{Hg}$ flux during colder periods to marine biological productivity and emissions of volatile $\mathrm{Hg}$ compounds from the ocean. The different results of the existing studies point to the gaps in our understanding of $\mathrm{Hg}$ behavior in productive remote areas, which warrants further investigation in the Southern Ocean.

In a previous paper, we discussed the accumulation of anthropogenic $\mathrm{Hg}$ in sediments of Adélie Basin, offshore East Antarctica. The $\sim 2$-fold increase in $\mathrm{Hg}$ concentrations and accumulation rates in the upper $\sim 2.80 \mathrm{~m}$ depth of the core was attributed to the onset of the industrial revolution and the strong increase in coal burning at $\sim 1850 \mathrm{CE}$ (Zaferani et al., 2018). Here, we discuss the natural processes (e.g., changes in biogenic and terrestrial material fluxes) that controlled $\mathrm{Hg}$ accumulation in the same sediment core prior to $1850 \mathrm{CE}$ throughout the past 8600 years. We investigated a continuous $\sim 170 \mathrm{~m}$ long Holocene laminated diatom ooze sediment record from the Adélie Basin. Covering almost the entire Holocene, the core allows the determination of natural variations of $\mathrm{Hg}$ accumulation rates in these sediments prior to major anthropogenic influences. Our main objective was to investigate the influence of different $\mathrm{Hg}$ sources as well as climate-induced changes in biological productivity and terrestrial fluxes (through melting of glacier ice), which have controlled the sequestration of $\mathrm{Hg}$ in these sediments. To evaluate the influence of different biogeochemical processes on the $\mathrm{Hg}$ accumulation in sediments, with an emphasis on the role of changes in planktonic productivity, we combined the data on $\mathrm{Hg}$ accumulation with data derived from multielement analyses.

\section{Materials and methods}

\subsection{Study site and core collection}

Sediments of the Adélie Basin were collected during the Integrated Ocean Drilling Program (IODP) Expedition from hole U1357B 318 in 2010. U1357B is located on the continental shelf off Wilkes Land at the Mertz Glacier polynya (region of open water surrounded by sea ice), Antarctica $\left(66^{\circ} 24.7990 " \mathrm{~S}, 140^{\circ} 25.5705^{\prime \prime} \mathrm{E}\right)$, at about $1021.5 \mathrm{~m}$ water depth (Escutia et al., 2011) (Fig. 1). The total length of the recovered core is $170.7 \mathrm{~m}$, corresponding to nearly the entire Holocene (Escutia et al., 2011). The core was sliced by $5 \mathrm{~cm}^{3}$ plastic scoops to $1 \mathrm{~cm}$ slices. Samples in the upper core (3.2-25.05 m b.s.f.) were taken at $\sim 40 \mathrm{~cm}$ intervals (a resolution of $\sim 20$ years) and $\sim 400 \mathrm{~cm}$ intervals (a resolution of $\sim 200$ years) in deeper sections $(25.05-170.35 \mathrm{~m}$ b.s.f.), resulting in a total of 78 samples. Age data and age model (which is based on compound-specific ${ }^{14} \mathrm{C}$ dating) were obtained from Yamane et al. (2014).

The sediment core is characterized by light and dark laminations which are undisturbed by sea-level changes or glacial erosion (Denis et al., 2006; Escutia et al., 2011). Light laminations correspond to spring seasons when light and high nutrient levels promote intense phytoplankton blooms and are mainly composed of biogenic materials (mostly diatom with minor abundance of silicoflagellates, sponge spicules, radiolarians, and foraminifers). Dark layers correspond to the summer/autumn season when sea ice has retreated, and nutrient levels are low. Dark laminations are composed of a mixture of biogenic and terrigenous materials resulting from summer production in open water, with glacial and subglacial inputs, respectively. High levels of primary production in surface water of this region, coupled with rapid fluxes of biogenic debris directly to the seafloor, led to high sedimentation rates of up to $2.0 \mathrm{~cm} \mathrm{yr}^{-1}$ during the past 10000 years (Escutia et al., 2011). 


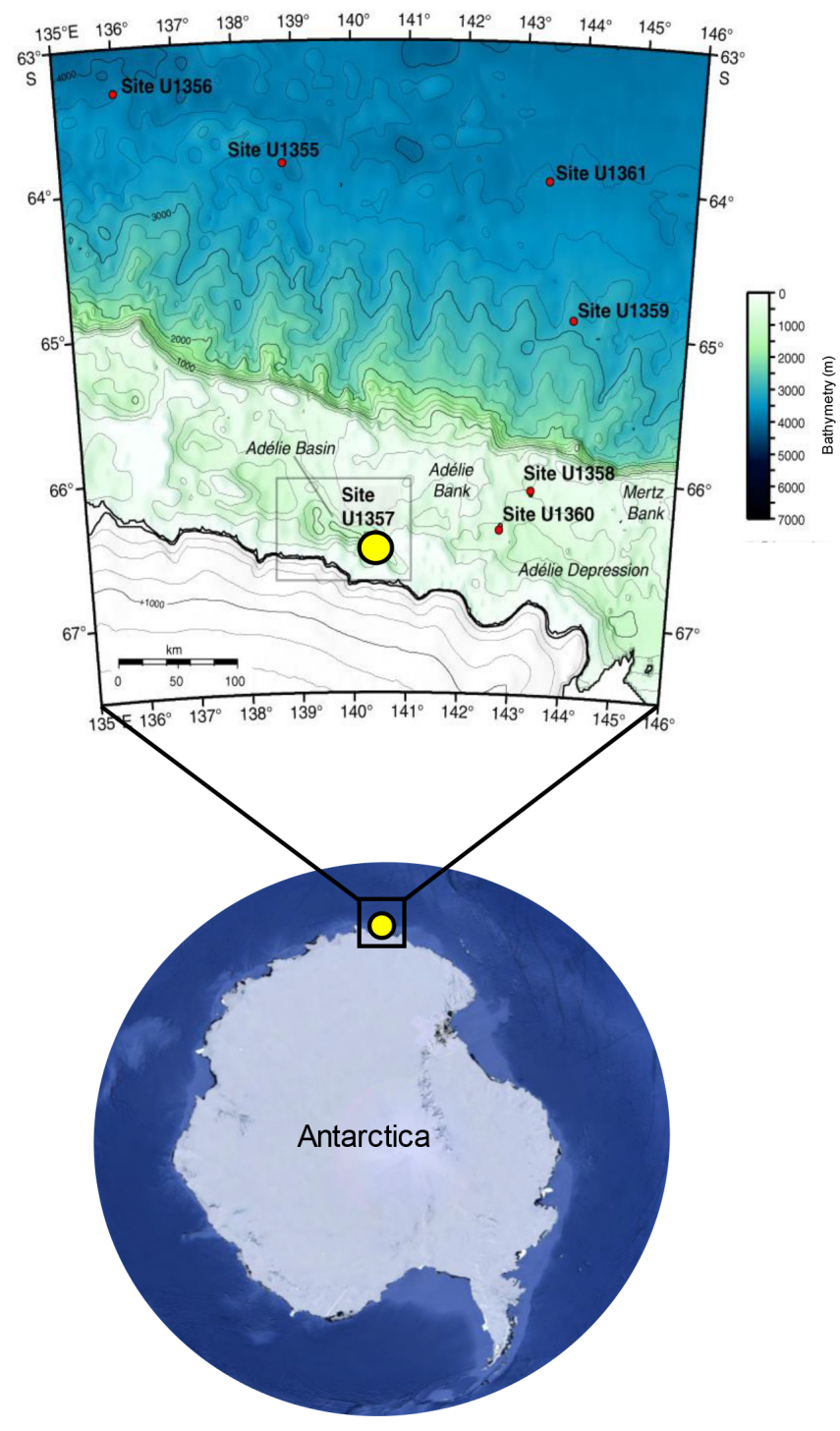

Figure 1. Location of the IODP318-U1357B core in the Adélie Basin, East Antarctica, indicated by a yellow dot (Antarctic image source (C) Google Earth; bathymetric map is reproduced from Escutia et al., 2011).

\subsection{Analyses of mercury and major and trace metals}

All samples were freeze-dried and ground using a glass pestle prior to geochemical analysis. Total $\mathrm{Hg}$ was determined by thermal decomposition followed by preconcentration of $\mathrm{Hg}$ on a gold trap and cold vapor atomic absorption spectrometry (CVAAS) $\mathrm{Hg}$ detection using a Milestone DMA-80 analyzer (US EPA Method 1998). The quality of the analysis was ensured by including a certified reference material (CRM) (Canmet LKSD-4 $=190 \pm 17 \mathrm{ng} \mathrm{g}^{-1}$ ) alongside the analyzed samples. The average measured concentration for LKSD-4 was $197 \pm 11 \mathrm{ng} \mathrm{g}^{-1}$. Replicate analyses $(n=20)$ were always within a relative standard deviation (RSD) of $10 \%$ of the certified value.
The samples were analyzed for concentrations of silicon $(\mathrm{Si})$, titanium $(\mathrm{Ti})$, zirconium $(\mathrm{Zr})$, sulfur $(\mathrm{S})$, calcium $(\mathrm{Ca})$, potassium $(\mathrm{K})$, aluminum $(\mathrm{Al})$, yttrium $(\mathrm{Y})$, manganese $(\mathrm{Mn})$, strontium $(\mathrm{Sr})$, iron $(\mathrm{Fe})$, lead $(\mathrm{Pb})$, copper $(\mathrm{Cu})$, zinc $(\mathrm{Zn})$, arsenic $(\mathrm{As})$, bromine $(\mathrm{Br})$, nickel $(\mathrm{Ni})$, chlorine $(\mathrm{Cl})$, and rubidium $(\mathrm{Rb})$ by energy dispersive $\mathrm{X}$-ray fluorescence (ED-XRF). The calibration method, accuracy, and precision are described in detail in Cheburkin and Shotyk (1996). The CRMs (Canmet LKSD-4, NRC/CNRC-PACS-2, NRC/CNRMess-3, and NCS-DC75304) and replicates were measured in each set of samples for accuracy and precision control. Repeated analysis of CRMs gave an RSD of less than $10 \%$ for $\mathrm{Si}, \mathrm{Al}, \mathrm{Ca}, \mathrm{Y}, \mathrm{Sr}, \mathrm{Zr}, \mathrm{Br}$, and $\mathrm{Rb} ; 6 \%-15 \%$ for $\mathrm{Ti}, \mathrm{K}$, $\mathrm{Zn}, \mathrm{S}, \mathrm{Fe}, \mathrm{Mn}$, and $\mathrm{Pb} ; 6 \%-19 \%$ for $\mathrm{Cl} ; 10 \%-20 \%$ for $\mathrm{Ni}$; $9 \%-14 \%$ for $\mathrm{Cu}$; and $14 \%-22 \%$ for As.

\subsection{Statistical analyses}

Principal component analysis (PCA) was applied to the major and trace element concentrations to identify processes controlling the variability of elements in the sediments. When there is a complex set of variables, PCA is used to reduce a large number of variables to a new set of artificial variables, called principal components. Each component includes variables with a similar down-core pattern. The principal components are then interpreted in terms of relevant geochemical processes that can control the variability of the major and trace elements in the sediments. The derived interpretation from PCA was then combined with the $\mathrm{Hg}$ data to examine the processes that could affect $\mathrm{Hg}$ accumulations. The analysis was performed on the standardized concentration data using $Z$ scores (expressed in terms of standard deviations from their means). Regression analysis of the corresponding residuals was used to establish relationships between the abundance of elements, by considering $\mathrm{Si}$ concentration as an independent variable and other element concentrations as dependent variables. Correlation analysis and PCA were performed using the statistical software SPSS 25.0.

\section{Results and discussion}

\subsection{Geochemical processes controlling the distribution of the elements in the sediments}

Concentration profiles and accumulation rates of $\mathrm{Si}, \mathrm{Al}, \mathrm{K}$, Ti, S, Ca, Zn, Fe, Br, As, and $\mathrm{Cl}$ are shown in Figs. 2-5. The preindustrial geochemical record of Adélie Basin sediments is generally characterized by periodic-like variations in the relative abundance of major and trace elements. The records of element accumulation rates largely follow those of periodic-like variations of concentrations and show no significant trend with depth (except $\mathrm{Cl}$ ).

Si has the highest concentration of all elements in the sediments. On one hand, Si is associated with the flux of ter- 


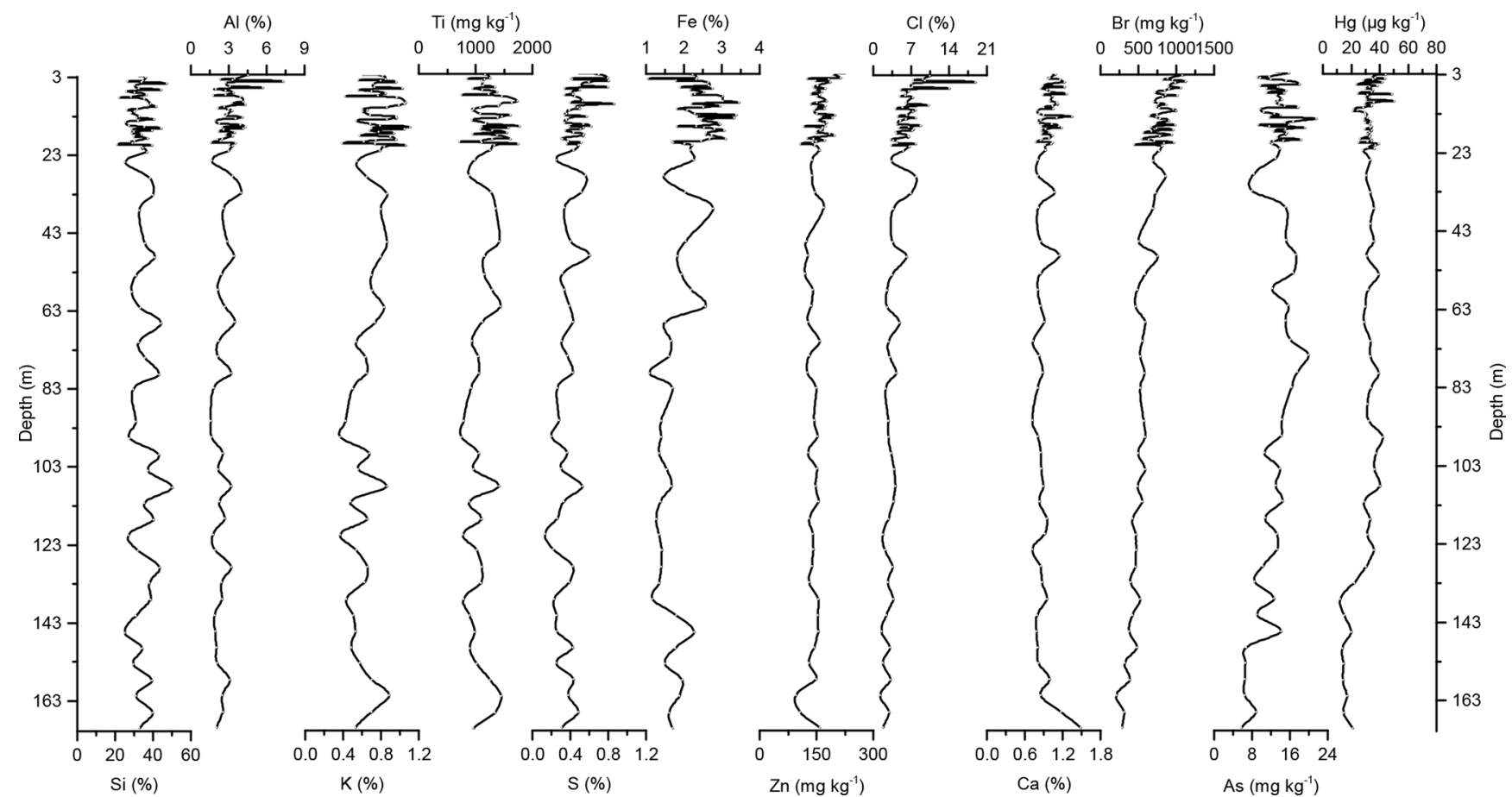

Figure 2. Down-core records of $\mathrm{Si}, \mathrm{Al}, \mathrm{K}, \mathrm{Ti}, \mathrm{S}, \mathrm{Fe}, \mathrm{Zn}, \mathrm{Cl}, \mathrm{Ca}, \mathrm{Br}, \mathrm{As}$, and $\mathrm{Hg}$ concentrations of Adélie Basin sediments.

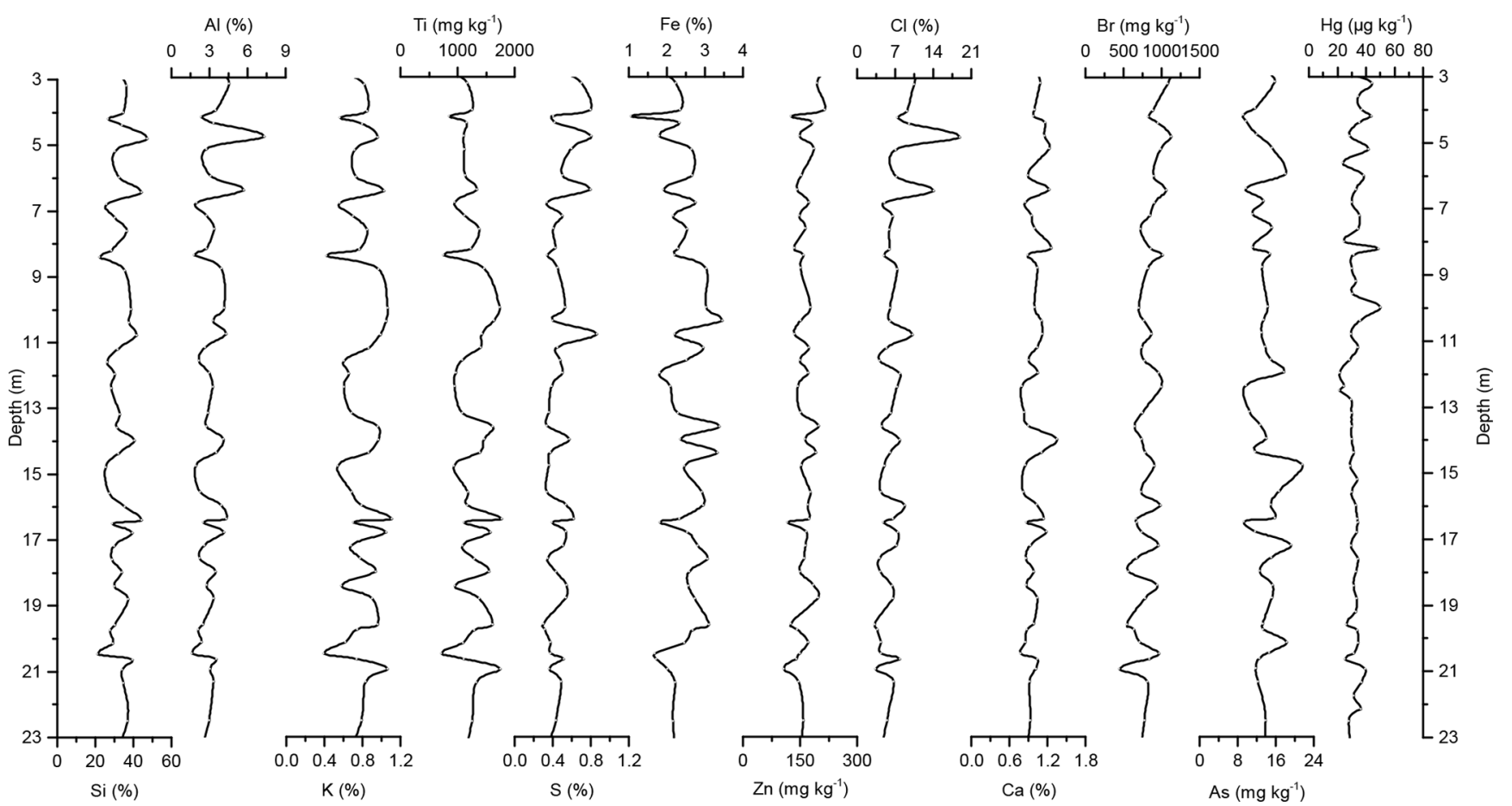

Figure 3. Down-core records of $\mathrm{Si}, \mathrm{Al}, \mathrm{K}, \mathrm{Ti}, \mathrm{S}, \mathrm{Fe}, \mathrm{Zn}, \mathrm{Cl}, \mathrm{Ca}, \mathrm{Br}, \mathrm{As}$, and $\mathrm{Hg}$ concentrations of Adélie Basin sediments for the top $23 \mathrm{~m}$ of the core. 


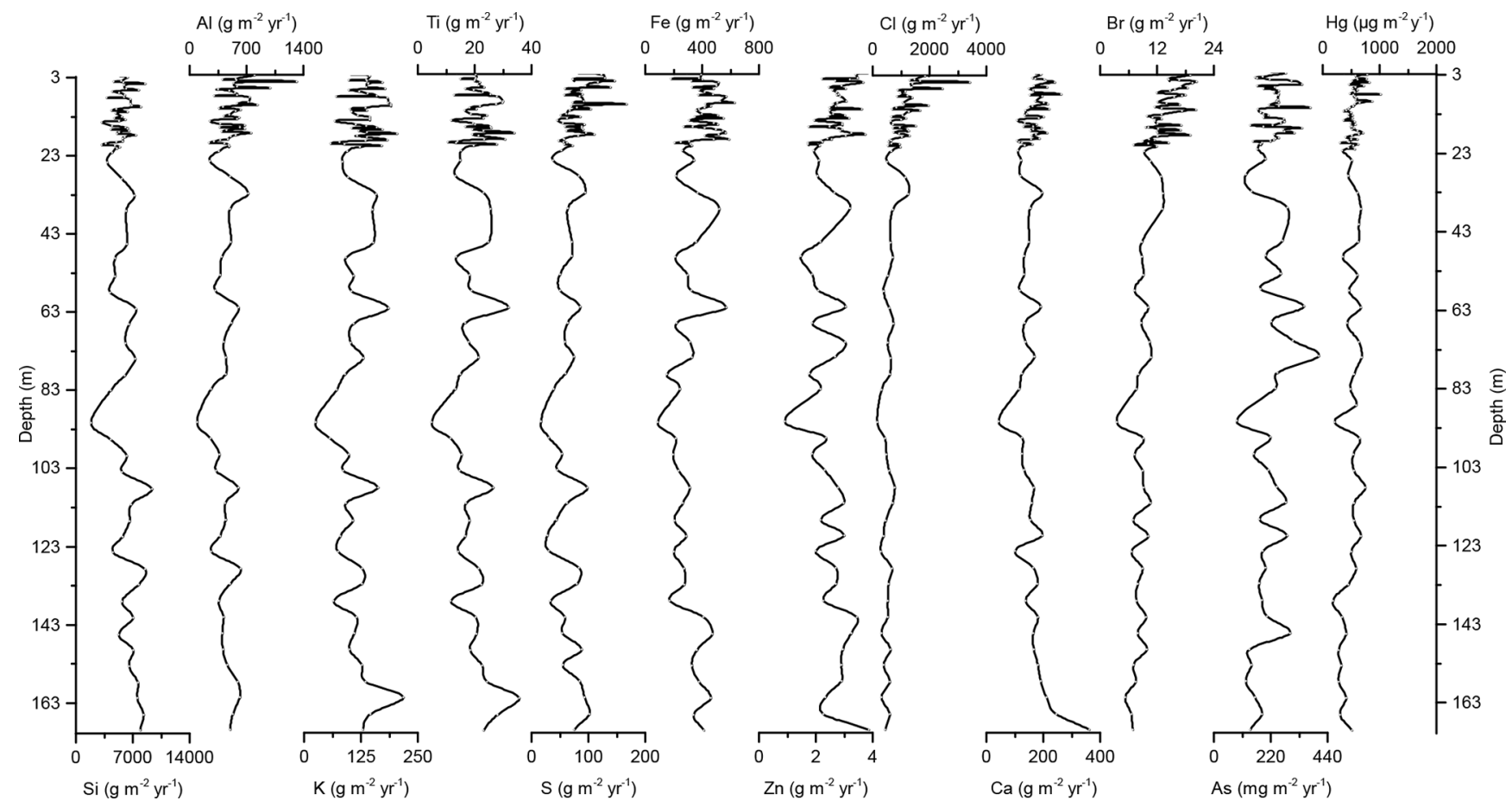

Figure 4. Down-core records of $\mathrm{Si}, \mathrm{Al}, \mathrm{K}, \mathrm{Ti}, \mathrm{S}, \mathrm{Fe}, \mathrm{Zn}, \mathrm{Cl}, \mathrm{Ca}, \mathrm{Br}, \mathrm{As}$, and $\mathrm{Hg}$ accumulation rates of Adélie Basin sediments.

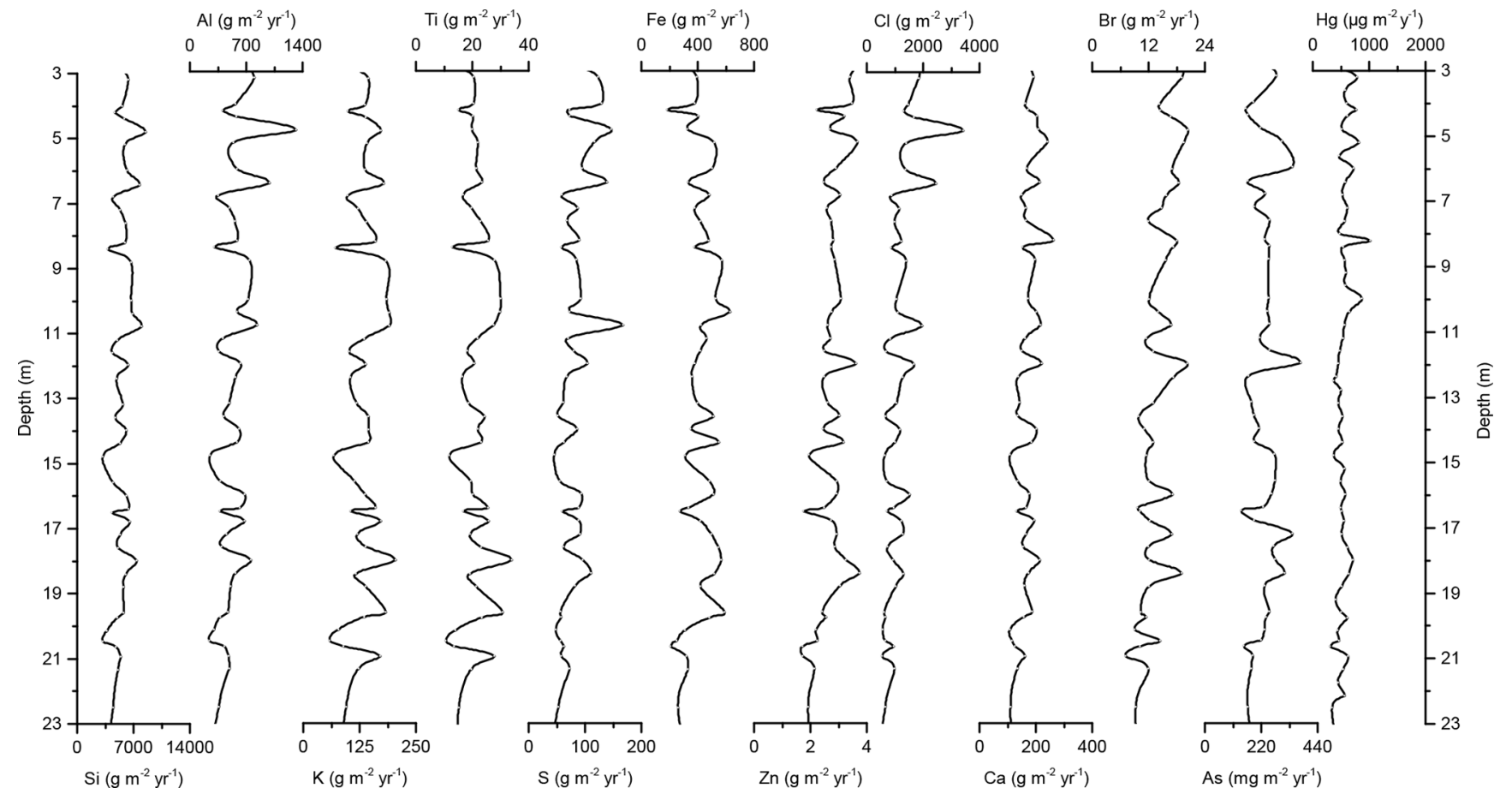

Figure 5. Down-core records of $\mathrm{Si}, \mathrm{Al}, \mathrm{K}, \mathrm{Ti}, \mathrm{S}, \mathrm{Fe}, \mathrm{Zn}, \mathrm{Cl}, \mathrm{Ca}, \mathrm{Br}$, As, and $\mathrm{Hg}$ accumulation rates of Adélie Basin sediments for the top $23 \mathrm{~m}$ of the core. 
restrial derived mineral components and on the other hand with siliceous phytoplankton, protozoans, protists, plant phytoliths, and sponge spicules (Croudace and Rothwell, 2015). $\mathrm{Si}$ is mainly biogenic in origin in Adélie Basin sediments, as well as dominated by diatoms (Escutia et al., 2011), and contribution of terrigenous $\mathrm{Si}$ is low. Therefore, it is used as a proxy for diatom abundance. The record of Si concentrations shows periodic-like variations by a factor of $\sim 2$ between $21 \%$ and $50 \%$, with a median of $33 \%$, corresponding to $70 \% \mathrm{SiO}_{2}$ or biogenic silica. Concentrations of $\mathrm{Al}$, $\mathrm{K}$, and $\mathrm{Ti}$ (as indicators of changes in the flux of lithogenic materials) range between $\sim 1.6 \%-7.3 \%, \sim 0.37 \%-1.11 \%$, and $\sim 716-1778 \mathrm{mg} \mathrm{kg}^{-1}$, respectively. S and Ca concentrations, which are associated with the biogenic productivity, vary between $\sim 0.13 \%-0.87 \%$ and $0.72 \%-1.49 \%$, respectively. Ca concentration indicates that calcite-producing microorganisms are of minor importance in the Adélie Basin. Concentration of $\mathrm{Zn}$, an important micronutrient for marine phytoplankton (Morel et al., 1994), ranges between $\sim 96$ and $216 \mathrm{~m} \mathrm{~kg}^{-1}$. Fe is another essential micronutrient for marine primary production (Smetacek et al., 2012) and biochemical processes of phytoplankton such as photosynthesis, respiration, and nitrogen fixation (Lohan and Tagliabue, 2018). Concentration of $\mathrm{Fe}$ varies between $\sim 1.05 \%$ and $3.46 \%$, which is similar to other siliceous sediments but lower than the reported concentration in other ocean sediments (Chen et al., 1996). Fe concentrations increase at $66.45 \mathrm{~m}$ depth to the top of the core by a factor of $\sim 1.6$ (from a median of $\sim 1.50 \%$ below the $66.45 \mathrm{~m}$ depth to $\sim 2.40 \%$ above the $66.45 \mathrm{~m}$ depth). This is attributed to the upward transport of $\mathrm{Fe}$ under anoxic conditions. Chlorine was found to be another major component in these sediments. $\mathrm{Cl}$ can go through biological pathways (incorporation into algae) and reach the sediments by the fast-sinking detritus (Leri et al., 2015). Concentrations vary between $\sim 1.3 \%$ and $19 \%$, with a median of median $4.5 \%$ and show a decrease from the top to the bottom of the core, which is likely attributed to the increasing mineralization of organic matter with age and the release of chloride through reductive dechlorination.

The PCA resulted in five components, explaining almost $82 \%$ of the total variance (Table 1 ). The first component (Cp1) explains $33 \%$ of the variance and shows large $(>0.7)$ positive loadings of $\mathrm{Mn}, \mathrm{Ti}, \mathrm{Rb}, \mathrm{Zr}, \mathrm{K}$, and $\mathrm{Y}$ and moderate positive loading of $\mathrm{Fe}$. The second component $(\mathrm{Cp} 2)$, which explains $20 \%$ of the variance, is characterized by large positive loadings of $\mathrm{Al}, \mathrm{Si}, \mathrm{S}$, and $\mathrm{Cl}$ and moderate positive loading of $\mathrm{K}$ and $\mathrm{Ca}$. The third component (Cp3) explains $17 \%$ of the variance and shows large positive loadings of $\mathrm{Zn}, \mathrm{Cu}$, and $\mathrm{Ni}$ and moderate positive loading of $\mathrm{Fe}$. The fourth and fifth components ( $\mathrm{Cp} 4$ and $\mathrm{Cp} 5$ ) account for $7 \%$ and $5 \%$ of the variance, respectively. $\mathrm{Cp} 4$ is characterized by high positive loadings for $\mathrm{Hg}$ and $\mathrm{As}$ and moderate negative loading of $\mathrm{Pb} . \mathrm{Cp} 5$ shows positive loadings for $\mathrm{Sr}$ and $\mathrm{Ca}$.

In general, results of PCA imply that opening and closing of the polynya and biological production are the most impor-
Table 1. Factor loadings for the five significant components extracted by PCA from Adélie Basin sediment samples. Component loadings $\geq 0.5$ are in bold.

\begin{tabular}{lrrrrr}
\hline Elements & \multicolumn{5}{c}{ Components } \\
\cline { 2 - 6 } & 1 & 2 & 3 & 4 & 5 \\
\hline $\mathrm{Mn}$ & $\mathbf{0 . 8 9}$ & 0.40 & -0.05 & -0.05 & 0.01 \\
$\mathrm{Ti}$ & $\mathbf{0 . 8 9}$ & 0.43 & 0.01 & 0.04 & -0.02 \\
$\mathrm{Rb}$ & $\mathbf{0 . 8 4}$ & 0.03 & 0.39 & 0.10 & 0.20 \\
$\mathrm{Zr}$ & $\mathbf{0 . 8 3}$ & -0.22 & 0.05 & -0.15 & 0.08 \\
$\mathrm{~K}$ & $\mathbf{0 . 7 3}$ & $\mathbf{0 . 6 6}$ & 0.05 & 0.08 & 0.10 \\
$\mathrm{Y}$ & $\mathbf{0 . 7 3}$ & -0.34 & 0.10 & -0.09 & 0.05 \\
$\mathrm{Al}$ & 0.12 & $\mathbf{0 . 9 3}$ & 0.06 & 0.05 & 0.18 \\
$\mathrm{Si}$ & 0.03 & $\mathbf{0 . 8 4}$ & -0.28 & -0.11 & -0.28 \\
$\mathrm{~S}$ & 0.01 & $\mathbf{0 . 8 4}$ & 0.16 & 0.12 & 0.26 \\
$\mathrm{Cl}$ & -0.16 & $\mathbf{0 . 7 6}$ & 0.25 & 0.22 & 0.42 \\
$\mathrm{Zn}$ & -0.05 & 0.15 & $\mathbf{0 . 7 8}$ & 0.15 & 0.11 \\
$\mathrm{Cu}$ & 0.31 & 0.03 & $\mathbf{0 . 7 6}$ & 0.31 & 0.21 \\
$\mathrm{Ni}$ & 0.11 & -0.08 & $\mathbf{0 . 7 5}$ & -0.10 & 0.00 \\
$\mathrm{Fe}$ & $\mathbf{0 . 6 2}$ & 0.03 & $\mathbf{0 . 6 4}$ & 0.20 & 0.19 \\
$\mathrm{Br}$ & -0.23 & 0.35 & $\mathbf{0 . 5 0}$ & 0.46 & 0.48 \\
$\mathrm{Hg}$ & 0.17 & 0.09 & -0.04 & $\mathbf{0 . 7 9}$ & 0.14 \\
$\mathrm{As}$ & -0.01 & -0.09 & 0.30 & $\mathbf{0 . 7 3}$ & -0.26 \\
$\mathrm{~Pb}$ & 0.35 & -0.11 & -0.10 & $-\mathbf{0 . 6 2}$ & -0.18 \\
$\mathrm{Sr}$ & 0.25 & 0.09 & 0.37 & 0.16 & $\mathbf{0 . 8 3}$ \\
$\mathrm{Ca}$ & 0.22 & $\mathbf{0 . 5 2}$ & -0.03 & -0.13 & $\mathbf{0 . 6 7}$ \\
\hline $\mathrm{Eigenvalue}$ & 6.62 & 3.95 & 3.34 & 1.35 & 0.98 \\
\hline \% variance & 33.1 & 19.7 & 16.7 & 6.7 & 4.9 \\
\hline & & & & &
\end{tabular}

tant factors influencing sedimentation in the Adélie Basin. This has been shown by loadings of elemental proxies for terrigenous and biological material inputs. Briefly, $\mathrm{Cp} 1$, which includes positive loadings of lithogenic elements, represents the variability of terrigenous inputs. Melting of ice releases trapped lithogenic material into the water and leads to the sinking of lithogenic particles and their sedimentation. Cp2 comprises loadings of elements of both biogenic and terrigenous sources. This component appears to reflect phytoplankton blooms and export of biological materials. After ice melt, when the ice is opening, favorable conditions for biological productivity lead to phytoplankton blooms and export of biogenic materials to the seafloor (Denis et al., 2006). Biogenic material is mainly opal because diatoms are a major component of blooms in the Adélie Basin (Escutia et al., 2011). The sinking of diatoms from the surface and their sedimentation can cause scavenging of elements during bloom time. $\mathrm{Al}$ shows positive loadings in this component rather than in $\mathrm{Cp} 1$. This, other than association with the flux of aluminosilicates material, can also be attributed to the scavenging of $\mathrm{Al}$ by diatom particles (Moran and Moore, 1992). $\mathrm{Cl}$ also shows loading in $\mathrm{Cp} 2$. The possible explanation for the observed covariation is that marine phytoplankton is rich in polyunsaturated lipids and can account as chlorination substrates (Leri 
et al., 2015). However, the organic $\mathrm{C}$ content of Adélie Basin sediments is generally low (between $1 \mathrm{wt} \%$ and $2 \mathrm{wt} \%$ ), and we hypothesize that some of the $\mathrm{Cl}$ must be in an inorganic form trapped in sediments owing to high sedimentation rates. $\mathrm{Cp} 3$ is mainly characterized by elements that are associated with the organic fraction of diatom cells. This component appears to reflect the remineralization process like decomposition of organic particles during sinking. Trace elements associated with organic parts of cells can be released back into the water column during decomposition. Therefore, cellular locations of elements, i.e., opal frustules of diatoms or organic matter of diatom cells, created different components of $\mathrm{Cp} 2$ and $\mathrm{Cp} 3$. Cp4 consists of organic particle reactive metals, e.g., $\mathrm{Hg}$ and $\mathrm{Pb}$. The possible explanation for not having these two particle reactive metals in $\mathrm{Cp} 2$ is that a portion of these two metals begins to enter the system after ice melting, while $\mathrm{Cp} 2$ shows scavenging of elements by diatoms that are already present in the water column. Since $\mathrm{Pb}$ and $\mathrm{Hg}$ are negatively correlated, this component cannot reflect a pollution signal. The reason for that could be the characteristic of $\mathrm{Pb}$ that decreases its impact in remote areas such as Antarctica. Atmospheric $\mathrm{Pb}$ is associated with particles and therefore is rapidly removed by wet and dry deposition. Moreover, the Southern Ocean circumpolar vortex that isolates Antarctica from the other continental landmasses in the Southern Hemisphere will further limit $\mathrm{Pb}$ transport to Antarctica. Covariation of $\mathrm{Ca}$ and $\mathrm{Sr}$ in $\mathrm{Cp} 5$ represents sedimentation of planktonic foraminifera, which appears to be of minor importance here.

Cp1 explains $33 \%$ of the variance and accounts for much of the variability/process which controlled the geochemical composition of these sediments. However, the high concentration of $\mathrm{Si}$ and low concentrations of terrigenous elements imply that in an environment like Adélie Basin, with extremely high productivity, input of lithogenic materials is changing while different diatom taxa are always present in the system, e.g., as sea-ice-associated and open-ocean diatom (Escutia et al., 2011).

It has been shown before that seasonal blooms in ocean surface waters result in temporary variable fluxes of elements to the deep ocean (Fowler and Knauer, 1986; Michel et al., 2002; Pilskaln et al., 2004). Although the core was not sampled at a 1-year resolution in our study, we suggest that the fluctuations of elemental concentrations are likely related to the seasonal blooms and variation of sea surface conditions like ice melting and freezing and its subsequent biological or terrestrial material exports. Sampling in light (associated with spring) or dark (associated with summer/autumn) laminae, which contains different amounts of biogenic or terrestrial materials, can cause the observed variations (see Sect. 2.1).

The element concentrations are comparable to other published sediment data, while the accumulation rates are much higher than other reported values. The existence of rapidly settling particles in the Adélie Basin can explain the high el- ement accumulation rates. When nonessential elements and essential elements show high accumulation rates, it is tempting to suggest that most elements in the water column of Adélie Basin are subjected to removal by intense phytoplankton blooms through consumption or scavenging. This agrees with the study of Fowler and Knauer (1986) that demonstrated the role of large particles in the transport of elements through the oceanic water column. Aggregations of diatoms, which create large particles (Turner, 2015), sink to the seafloor and can create a space in which elements can be trapped (Shanks and Trent, 1979). This enhances removal of elements from the water column and their sedimentation as well.

\subsection{Holocene record of mercury concentrations and accumulation rates}

In the preindustrial period, i.e., from the bottom of the core at $\sim 170$ to $2.80 \mathrm{~m}$ depth ( 8600 years ago to $\sim 1850 \mathrm{CE}$ ), the $\mathrm{Hg}$ record shows no obvious trend with depth but rather periodic-like variations. Hg concentrations fluctuate by a factor of about 2 between 12.6 and $21.1 \mu^{-1 \mathrm{gg}^{-1}}$ within 170 $137 \mathrm{~m}$ depth and between 21.7 and $44.6 \mu \mathrm{g} \mathrm{kg}^{-1}$ within 137$2.80 \mathrm{~m}$ depth of the core, with two more pronounced peaks at around 9.99 and $8.20 \mathrm{~m}$ depth (Figs. 2 and 3). The lower concentration of $\mathrm{Hg}$ within 170-137 m depth of the core is probably attributed to cooler conditions in Adélie Basin (Crosta et al., 2007) and sea ice cover during this period. Hg accumulation rates in the preindustrial period (Figs. 4 and 5) largely follow the $\mathrm{Hg}$ concentration record, with periodic-like variations and a median of $556 \mu \mathrm{g} \mathrm{m}^{-2} \mathrm{yr}^{-1}$, which largely surpass the reported $\mathrm{Hg}$ deposition rates to the oceans (Mason and Sheu, 2002).

The high preindustrial $\mathrm{Hg}$ accumulation rates in Adélie Basin sediments cannot be explained by preindustrial atmospheric $\mathrm{Hg}$ depositions alone, which did not exceed $20 \mu \mathrm{g} \mathrm{m}^{-2}$ as recorded in an Antarctic ice core (Vandal et al., 1993). Therefore, nonatmospheric sources, such as dissolved water-phase $\mathrm{Hg}$ or terrestrial inputs, are needed for the observed high $\mathrm{Hg}$ enrichment in these sediments.

To identify driving forces behind the variations in $\mathrm{Hg}$ accumulation we used our PCA results. PCA demonstrated that two main processes, i.e., biogenic productivity and lithogenic inputs, controlled the flux of elements to Adélie Basin sediments. The component scores, which illustrate the depth dependency of the extracted components, are characterized by seesaw patterns throughout the entire core. This indicates different contributions of biogenic and terrigenous inputs most likely associated with spring and summer/autumn seasons, respectively.

The variance of $\mathrm{Hg}$ was not captured by $\mathrm{Cp} 1, \mathrm{Cp} 2$, or $\mathrm{Cp} 3$. $\mathrm{Hg}$ instead forms a group on $\mathrm{Cp} 4$ together with positive loading of As and negative loading of $\mathrm{Pb}$. The absence of significant loading of $\mathrm{Hg}$ on $\mathrm{Cp} 1, \mathrm{Cp} 2$, and $\mathrm{Cp} 3$ (Table 1) and the lack of similarity between component scores and $\mathrm{Hg}$ concen- 


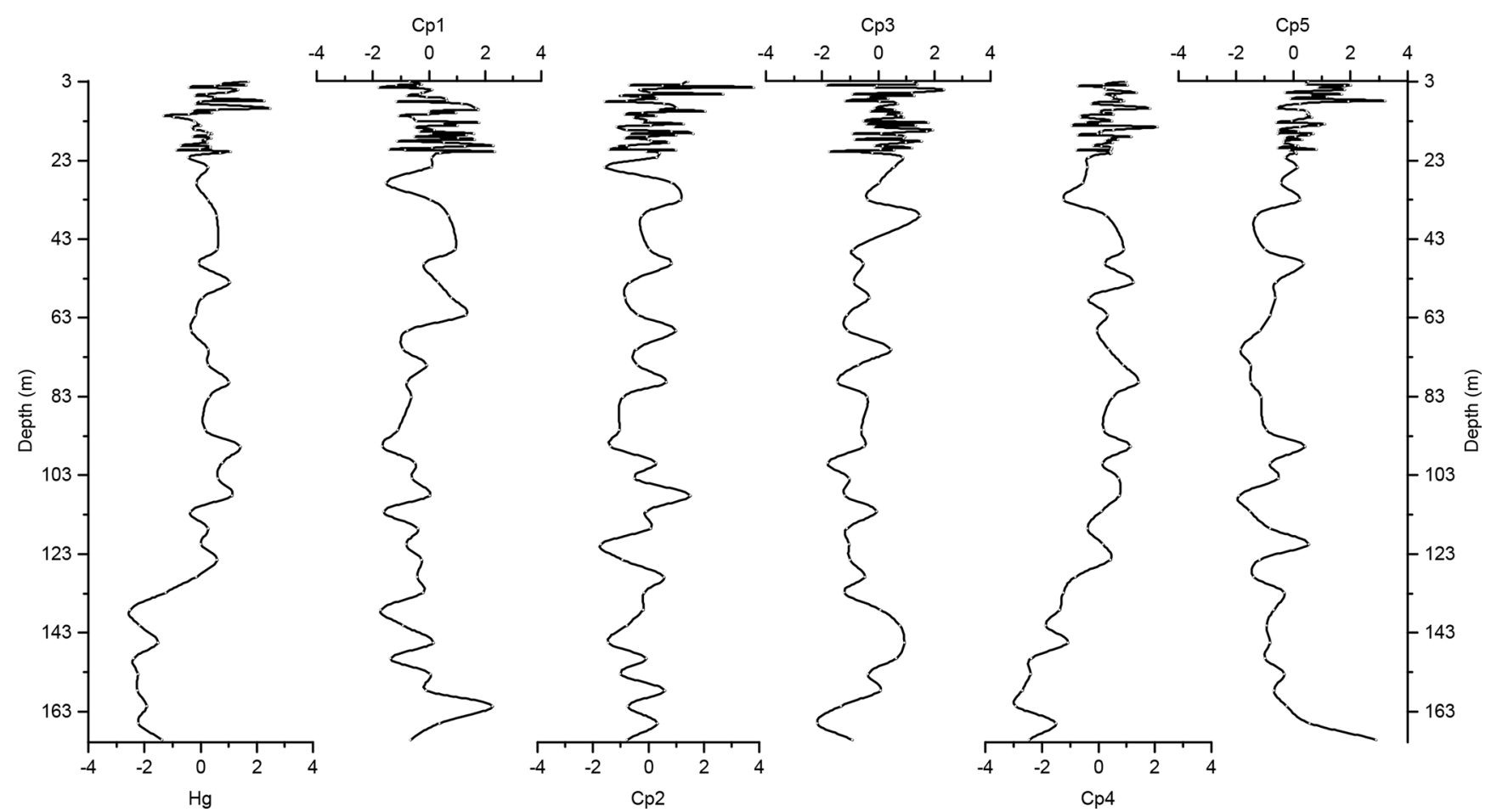

Figure 6. Depth records of scores of the principal components extracted by PCA on the elemental composition of the sediments along with $\mathrm{Z}$ score of $\mathrm{Hg}$ of the Adélie Basin sediments.

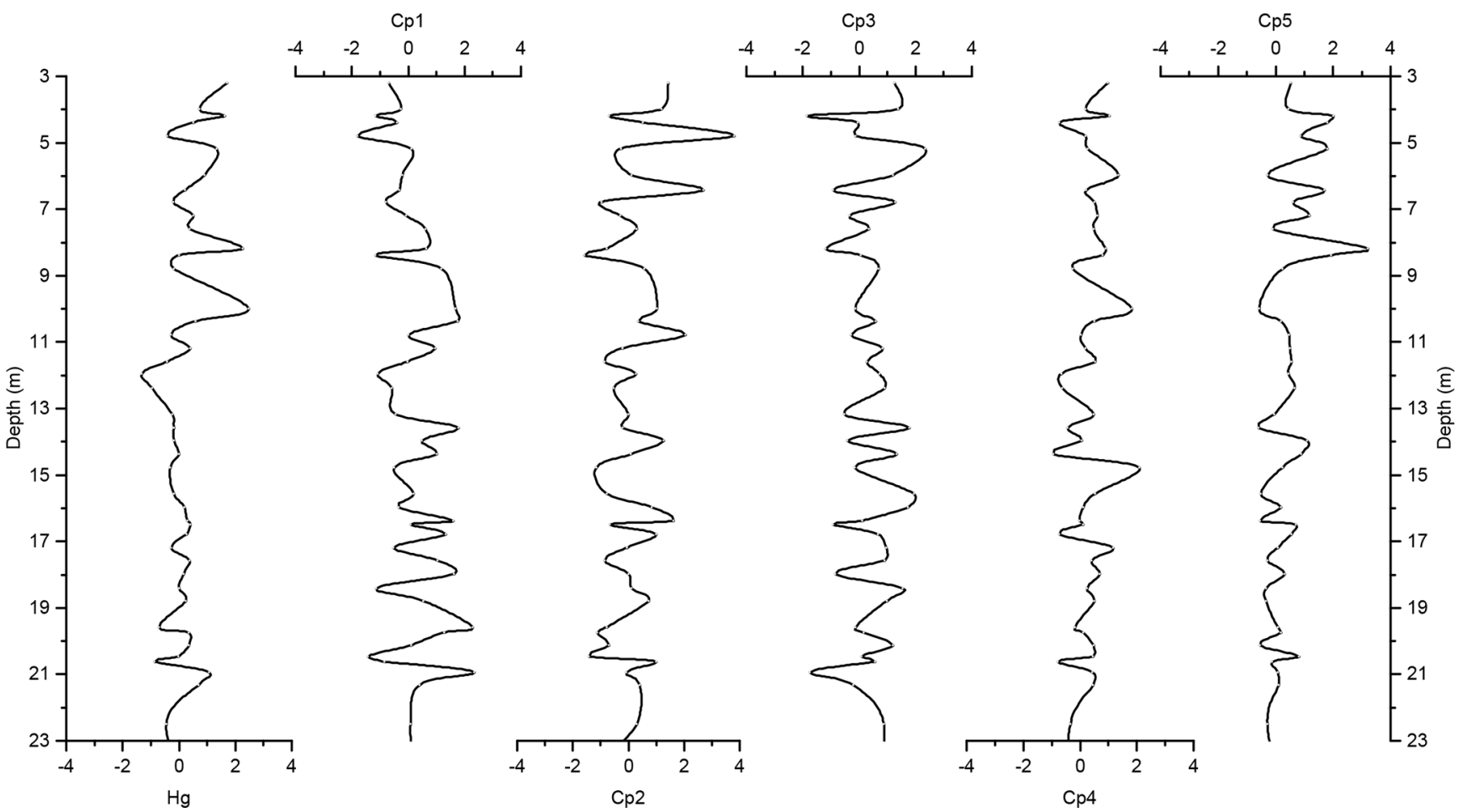

Figure 7. Depth records of scores of the principal components extracted by PCA on the elemental composition of the sediments along with $\mathrm{Z}$ score of $\mathrm{Hg}$ of the Adélie Basin sediments for the top $23 \mathrm{~m}$ of the core. 

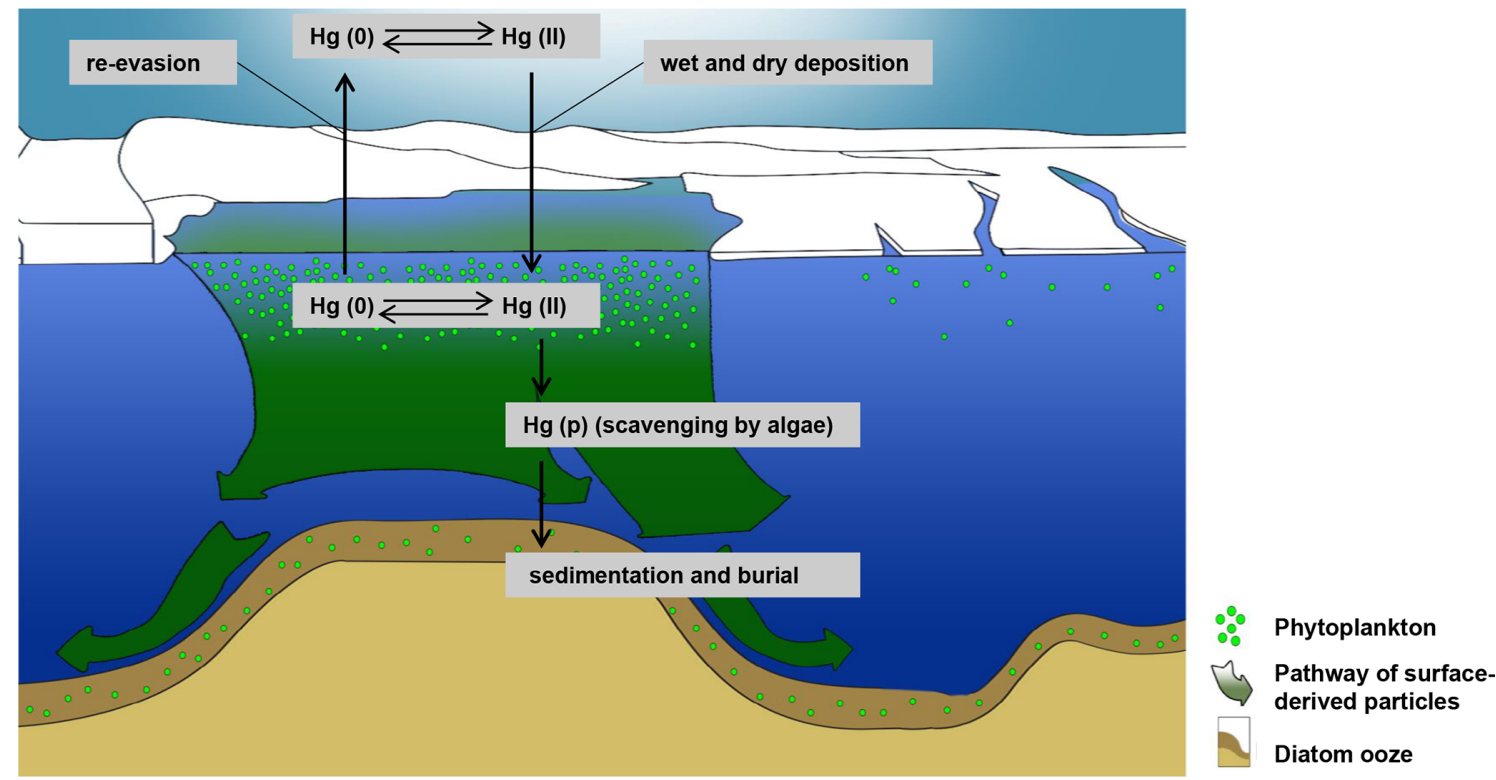

Figure 8. Adélie Basin schematic $\mathrm{Hg}$ cycle model indicating the processes controlling $\mathrm{Hg}$ deposition and accumulation under high primary production. Fast-sinking diatom particles remove dissolved water-phase $\mathrm{Hg}$ from the water column through scavenging (figure is adapted from Jansen et al., 2018).

trations (Figs. 6 and 7), in the preindustrial period, indicate that $\mathrm{Hg}$ fluxes are not significantly influenced by changes in lithogenic inputs through ice melting. These results further indicate that changes in the contribution of biogenic material cannot explain the variation in $\mathrm{Hg}$ accumulation in the sediments.

Although, the high $\mathrm{Hg}$ accumulation rates observed in the Adélie Basin sediments could not be explained by atmospheric $\mathrm{Hg}$ deposition, but we expect that the $\mathrm{Hg}$ flux from the atmosphere will probably increase during algae blooms attributed to the removal of dissolved $\mathrm{Hg}$ through scavenging by algae. $\mathrm{Hg}$ removal from the upper water column by diatom organic matter will also likely decrease $\mathrm{Hg}$ re-evasion to the atmosphere as previously assumed in model studies (Soerensen et al., 2014, 2016).

We have hypothesized that the high $\mathrm{Hg}$ enrichment in Adélie Basin sediments has been caused by scavenging of dissolved water-phase $\mathrm{Hg}$ by a large amount of fast-sinking algal debris. To prove this hypothesis we calculated the maximum amount of $\mathrm{Hg}$ which could be scavenged by a single bloom event using the $\mathrm{Hg}$ concentration of $271 \pm 78 \mathrm{pg} \mathrm{L}^{-1}$ in Antarctic bottom water, as determined by Cossa et al. (2011). The amount of $\mathrm{Hg}$ in a water column of $1 \mathrm{~m}^{2}$ and $1000 \mathrm{~m}$ depth would then amount to $271 \pm 78 \mu \mathrm{g}$. This means that only about two to three algae blooms and scavenging events per year are necessary to obtain the average $\mathrm{Hg}$ accumulation rate in Adèlie Basin diatom ooze sediments, i.e., $556 \pm$ $137 \mu \mathrm{g} \mathrm{m}^{-2} \mathrm{yr}^{-1}$. This appears to be likely taking into account that bloom events are frequent during Antarctic summer and that the sinking speed of diatom agglomerates at
Adélie Basin is high (100-400 $\left.\mathrm{m} \mathrm{d}^{-1}\right)$ (Jansen et al., 2018). The annual cycle of water mass transformation beneath the Mertz Glacier polynya system (Williams et al., 2008) and the exchange of water masses can rapidly refill the $\mathrm{Hg}$ inventory in the water column after a scavenging event. While algal bloom is a local event at the surface water of the Adèlie Basin, the exchange of water masses, which have not been affected by algae blooms, could refill the Hg inventory in the water column (Fig. 8).

The main reason for not finding any statistical relation between $\mathrm{Hg}$ and biogenic materials is that the amount of algal material during blooms is always large and therefore not a limiting factor for the scavenging of $\mathrm{Hg}$. There has always been excess algal material within or passing through the water column to scavenge all water column $\mathrm{Hg}$. Thus, we assume that nearly all $\mathrm{Hg}$ in the water column is removed through scavenging during diatom blooms but that $\mathrm{Hg}$ scavenging events occur less frequently during winter and summer/autumn seasons when primary productivity is lower and open ice expansion is at its maximum. Similar to other elements, the periodic-like variations observed in the preindustrial $\mathrm{Hg}$ record. The influence of periodically climatic changes of phytoplankton activity on periodical changes of $\mathrm{Hg}$ content was suggested before for the Caribbean Sea (Kita et al., 2013). It is likely that the periodic-like variations observed in the Adèlie Basin $\mathrm{Hg}$ record are also attributed to the seasonal export of biological materials. This could be in line with findings of $\mathrm{Hg}$ levels in water (Canário et al., 2017), which suggested that different development stages of a phytoplankton bloom lead to different amounts of dissolved $\mathrm{Hg}$ 
taken up by phytoplankton. However, investigation at seasonal resolution is needed to further confirm our observations and hypotheses.

\section{Conclusions}

Investigation of Antarctic biogenic bottom sediments revealed that biological productivity and related scavenging of water-phase $\mathrm{Hg}$ by rapidly sinking algae or algaederived organic matter controlled preindustrial $\mathrm{Hg}$ accumulation in Adélie Basin, Antarctica. Our study suggests that the periodic-like variations in total $\mathrm{Hg}$ concentrations and accumulation rates are likely associated with the opening and closing of polynya and its related changes in biological productivity. Although the high $\mathrm{Hg}$ accumulation in diatom ooze does not represent the $\mathrm{Hg}$ sedimentation process across all the world's oceans, our data show that $\mathrm{Hg}$ scavenging by algae or fast-sinking algae-derived organic matter is a key process controlling the sequestration of $\mathrm{Hg}$ in marine sediments and therefore the marine biogeochemical cycle of $\mathrm{Hg}$ in general. This can be similar to the association between very high benthic organic $\mathrm{C}$ fluxes with diatom production at the surface water, which can be accelerated by aggregation (Sachs et al., 2009).

Our observations also suggest that re-emission of $\mathrm{Hg}$ from ocean surface waters as a result of reduction of $\mathrm{Hg}$ (II) might be reduced due to $\mathrm{Hg}$ scavenging by algae, at least in areas of high primary productivity ecosystems comparable to the Adélie Basin ecosystem setup. Moreover, $\mathrm{Hg}$ fluxes to marine sediments might be higher than previously assumed in global model estimations. More data from marine sediments are needed to support this assumption. A future increase in marine productivity including algae blooms especially in coastal areas and semiclosed shallow seas will likely increase the $\mathrm{Hg}$ flux to bottom sediments. The model study of Soerensen et al. (2016) for the Baltic Sea might serve as an example for changes in marine $\mathrm{Hg}$ cycling caused by eutrophication. The area of the seafloor which is covered by remains of calcareous phytoplankton needs to be considered in future studies as well owing to the role of calcareous species on $\mathrm{Hg}$ content (Kita et al., 2013).

Data availability. All data are available in the Supplement.

Supplement. The supplement related to this article is available online at: https://doi.org/10.5194/os-16-729-2020-supplement.

Author contributions. SZ carried out the analyses. HB planned the study and supervised the findings of this work. The manuscript was written by both authors.
Competing interests. The authors declare that they have no conflict of interest.

Acknowledgements. This research was supported by TU Braunschweig. We thank Petra Schmidt and Adelina Calean for technical assistance, as well as David McLagan for the constructive comments on the manuscript.

Financial support. This open-access publication was funded by Technische Universität Braunschweig.

Review statement. This paper was edited by Yuelu Jiang and reviewed by C. H. Lamborg and two anonymous referees.

\section{References}

Aksentov, K. I. and Sattarova, V. V.: Mercury geochemistry of deep-sea sediment cores from the Kuril area, northwest Pacific, Prog. Oceanogr., 180, 102235, https://doi.org/10.1016/j.pocean.2019.102235, 2020.

Amos, H. M., Jacob, D. J., Streets, D. G., and Sunderland, E. M.: Legacy impacts of all-time anthropogenic emissions on the global mercury cycle, Global Biogeochem. Cy., 27, 410-421, https://doi.org/10.1002/gbc.20040, 2013.

Amyot, M., Gill, G. A., and Morel, F. M. M.: Production and loss of dissolved gaseous mercury in coastal seawater, Environ. Sci. Technol., 31, 3606-3611, https://doi.org/10.1021/es9703685, 1997.

Arrigo, K. R., Worthen, D., Schnell, A., and Lizotte, M. P.: Primary production in Southern Ocean waters, J. Geophys. Res.-Ocean., 103, 15587-15600, https://doi.org/10.1029/98JC00930, 1998.

Canário, J., Santos-Echeandia, J., Padeiro, A., Amaro, E., Strass, V., Klaas, C., Hoppema, M., Ossebaar, S., Koch, B. P., and Laglera, L. M.: Mercury and methylmercury in the Atlantic sector of the Southern Ocean, Deep-Sea Res. Pt II, 138, 52-62, https://doi.org/10.1016/j.dsr2.2016.07.012, 2017.

Cheburkin, A. K. and Shotyk, W.: An energy-dispersive miniprobe multielement analyzer (EMMA) for direct analysis of $\mathrm{Pb}$ and other trace elements in peats, Fresen. J. Anal. Chem., 354, 688691, https://doi.org/10.1007/s0021663540688, 1996.

Chen, S.-Y., Ambe, S., Takematsu, N., and Ambe, F.: The chemical states of iron in marine sediments by means of Mössbauer spectroscopy in combination with chemical leachings, J. Oceanogr., 52, 705-715, https://doi.org/10.1007/BF02239461, 1996.

Cossa, D., Heimbu, L., Lannuzel, D., Rintoul, S. R., Butler, E. C. V, Bowie, A. R., Averty, B., Watson, R. J., and Remenyi, T.: Mercury in the Southern Ocean, Geochim. Cosmochim. Acta, 75, 4037-4052, https://doi.org/10.1016/j.gca.2011.05.001, 2011.

Crosta, X., Romero, O., Armand, L. K., and Pichon, J.-J.: The biogeography of major diatom taxa in Southern Ocean sediments: 2. Open ocean related species, Palaeogeogr. Palaeocl. Palaeoecol., 223, 66-92, https://doi.org/10.1016/j.palaeo.2005.02.015, 2005.

Crosta, X., Debret, M., Denis, D., Courty, M., and Ther, O.: Holocene long-and short-term climate changes off Adélie 
Land, East Antarctica, Geochem. Geophy. Geosy., 8, 1-15, https://doi.org/10.1029/2007GC001718, 2007.

Croudace, I. W. and Rothwell, R. G.: Micro-XRF Studies of Sediment Cores: Applications of a non-destructive tool for the environmental sciences, Springer, Dordrecht, https://doi.org/10.1007/978-94-017-9849-5, 2015.

Denis, D., Crosta, X., Zaragosi, S., Romero, O., Martin, B., and Mas, V.: Seasonal and subseasonal climate changes recorded in laminated diatom ooze sediments, Adelie Land, East Antarctica, The Holocene, 16, 1137-1147, https://doi.org/10.1177/0959683606069414, 2006.

Driscoll, C. T., Mason, R. P., Chan, H. M., Jacob, D. J., and Pirrone, N.: Mercury as a global pollutant: Sources, pathways, and effects, Environ. Sci. Technol., 47, 4967-4983, https://doi.org/10.1021/es305071v, 2013.

Escutia, C., Brinkhuis, H., Klaus, A., and Expedition 318 Scientists: Site U1357, Proc. Integr. Ocean Drill. Programprogr., 318, 12, https://doi.org/10.2204/iodp.proc.318.105.2011, 2011.

Fitzgerald, W. F., Gill, G. A., and Kim, J. P.: An equatorial Pacific Ocean source of atmospheric mercury, Science, 224, 597-599, https://doi.org/10.1126/science.224.4649.597, 1984.

Fitzgerald, W. F., Lamborg, C. H., and Hammerschmidt, C. R.: Marine biogeochemical cycling of mercury, Chem. Rev., 107, 641662, https://doi.org/10.1021/cr050353m, 2007.

Fowler, S. W. and Knauer, G. A.: Role of large particles in the transport of elements and organic compounds through the oceanic water column, Prog. Oceanogr., 16, 147-194, https://doi.org/10.1016/0079-6611(86)90032-7, 1986.

Fütterer, D. K.: The solid phase of marine sediments, in: Marine geochemistry, edited by: Schulz, H. D. and Zabel, M., 1-25, Springer, Berlin, Heidelberg, https://doi.org/10.1007/978-3-66204242-7_1, 2006.

Horowitz, H. M., Jacob, D. J., Zhang, Y., Dibble, T. S., Slemr, F., Amos, H. M., Schmidt, J. A., Corbitt, E. S., Marais, E. A., and Sunderland, E. M.: A new mechanism for atmospheric mercury redox chemistry: implications for the global mercury budget, Atmos. Chem. Phys., 17, 6353-6371, https://doi.org/10.5194/acp17-6353-2017, 2017.

Jansen, J., Hill, N. A., Dunstan, P. K., McKinlay, J., Sumner, M. D., Post, A. L., Eléaume, M. P., Armand, L. K., Warnock, J. P., Galton-Fenzi, B. K., and Johnson, C. R.: Abundance and richness of key Antarctic seafloor fauna correlates with modelled food availability, Nat. Ecol. Evol., 2, 71-80, https://doi.org/10.1038/s41559-017-0392-3, 2018.

Kita, I., Kojima, M., Hasegawa, H., Chiyonobu, S., and Sato, T.: Mercury content as a new indicator of ocean stratification and primary productivity in Quaternary sediments off Bahama Bank in the Caribbean Sea, Quat. Res., 80, 606-613, https://doi.org/10.1016/j.yqres.2013.08.006, 2013.

Lamborg, C., Bowman, K., Hammerschmidt, C., Gilmour, C., Munson, K., Selin, N., and Tseng, C.-M.: Mercury in the Anthropocene Ocean, Oceanography, 27, 76-87, https://doi.org/10.5670/oceanog.2014.11, 2014a.

Lamborg, C. H., Hammerschmidt, C. R., Bowman, K. L., Swarr, G. J., Munson, K. M., Ohnemus, D. C., Lam, P. J., Heimbürger, L., Rijkenberg, M. J. A., and Saito, M. A.: A global ocean inventory of anthropogenic mercury based on water column measurements, Nature, 512, 65-68, https://doi.org/10.1038/nature13563, 2014 b.
Lamborg, C. H., Hammerschmidt, C. R., and Bowman, K. L.: An examination of the role of particles in oceanic mercury cycling, Philos. T. Roy. Soc. A, 374, 20150297, https://doi.org/10.1098/rsta.2015.0297, 2016.

Le Faucheur, S., Campbell, P. G., Fortin, C., and Slaveykova, V. I.: Interactions between mercury and phytoplankton: speciation, bioavailability, and internal handling, Environ. Toxicol. Chem., 33, 1211-1224, https://doi.org/10.1002/etc.2424, 2014.

Leri, A. C., Mayer, L. M., Thornton, K. R., Northrup, P. A., Dunigan, M. R., Ness, K. J., and Gellis, A. B.: A marine sink for chlorine in natural organic matter, Nat. Geosci., 8, 620-624, https://doi.org/10.1038/ngeo2481, 2015.

Lohan, M. C. and Tagliabue, A.: Oceanic micronutrients: trace metals that are essential for marine life, Elements, 14, 385-390, https://doi.org/10.2138/gselements.14.6.385, 2018.

Mason, R. and Fitzgerald, W. F.: The distribution and biogeochemical cycling of mercury in the equatorial Pacific Ocean, DeepSea Res. Pt. I, 40, 1897-1924, https://doi.org/10.1016/09670637(93)90037-4, 1993.

Mason, R. and Sheu, G.-R.: Role of the ocean in the global mercury cycle, Global Biogeochem. Cy., 16, 1-14, https://doi.org/10.1029/2001GB001440, 2002.

Mason, R., Rolfhus, K. R., and Fitzgerald, W. F.: Methylated and elemental mercury cycling in surface and deep ocean waters of the North Atlantic, Water Air Soil Poll., 80, 665-677, https://doi.org/10.1007/BF01189719, 1995.

Mason, R., Lawson, N. M., and Sheu, G. R.: Mercury in the atlantic ocean: Factors controlling air-sea exchange of mercury and its distribution in the upper waters, Deep-Sea Res. Pt. II, 48, 28292853, https://doi.org/10.1016/S0967-0645(01)00020-0, 2001.

Mason, R. P., Fitzgerald, W. F., and Morel, F. M.: The biogeochemical cycling of elemental mercury: anthropogenic influences, Geochim. Cosmochim. Acta, 58, 3191-3198, https://doi.org/10.1016/0016-7037(94)90046-9, 1994.

Mason, R. P., Reinfelder, J. R., and Morel, F. M.: Uptake, Toxicity, and Trophic Transfer of Mercury in a Coastal Diatom, Environ. Sci. Technol., 30, 1835-1845, https://doi.org/10.1021/es950373d, 1996.

Mason, R. P., Choi, A. L., Fitzgerald, W. F., Hammerschmidt, C. R., Lamborg, C. H., Soerensen, A. L., and Sunderland, E. M.: Mercury biogeochemical cycling in the ocean and policy implications, Environ. Res., 119, 101-117, https://doi.org/10.1016/j.envres.2012.03.013, 2012.

Michel, C., Gosselin, M., and Nozais, C.: Preferential sinking export of biogenic silica during the spring and summer in the North Water Polynya (northern Baffin Bay): Temperature or biological control?, J. Geophys. Res.-Ocean., 107, 1-1, https://doi.org/10.1029/2000jc000408, 2002.

Moran, S. and Moore, R.: Kinetics of the removal of dissolved aluminum by diatoms in seawater: A comparison with thorium, Geochim. Cosmochim. Acta, 56, 3365-3374, https://doi.org/10.1016/0016-7037(92)90384-U, 1992.

Morel, F. M. and Price, N.: The biogeochemical cycles of trace metals in the oceans, Science, 300, 944-947, https://doi.org/10.1126/science.1083545, 2003.

Morel, F. M. M., Reinfelder, J. R., Roberts, S. B., Chamberlain, C. P., Lee, J. G., and Yee, D.: Zinc and carbon colimitation of marine phytoplankton, Nature, 369, 740-742, https://doi.org/10.1038/369740a0, 1994. 
Nerentorp Mastromonaco, M. G., Gårdfeldt, K., and Langer, S.: Mercury flux over West Antarctic Seas during winter, spring and summer, Mar. Chem., 193, 44-54, https://doi.org/10.1016/j.marchem.2016.08.005, 2017a.

Nerentorp Mastromonaco, M. G., Gårdfeldt, K., Assmann, K. M., Langer, S., Delali, T., Shlyapnikov, Y. M., Zivkovic, I., and Horvat, M.: Speciation of mercury in the waters of the Weddell, Amundsen and Ross Seas (Southern Ocean), Mar. Chem., 193, 20-33, https://doi.org/10.1016/j.marchem.2017.03.001, 2017b.

O'Driscoll, N. J., Siciliano, S. D., Lean, D. R. S., and Amyot, M.: Gross photoreduction kinetics of mercury in temperate freshwater lakes and rivers: Application to a general model of DGM dynamics, Environ. Sci. Technol., 40, 837-843, https://doi.org/10.1021/es051062y, 2006.

Pilskaln, C. H., Manganini, S. J., Trull, T. W., Armand, L., Howard, W., Asper, V. L., and Massom, R.: Geochemical particle fluxes in the Southern Indian Ocean seasonal ice zone: Prydz Bay region, East Antarctica, Deep-Sea Res. Pt. I, 51, 307-332, https://doi.org/10.1016/j.dsr.2003.10.010, 2004.

Qureshi, A., O'Driscoll, N. J., Macleod, M., Neuhold, Y. M., and Hungerbühler, K.: Photoreactions of mercury in surface ocean water: Gross reaction kinetics and possible pathways, Environ. Sci. Technol., 44, 644-649, https://doi.org/10.1021/es9012728, 2010.

Rolfhus, K. R. and Fitzgerald, W. F.: Mechanisms and temporal variability of dissolved gaseous mercury production in coastal seawater, Mar. Chem., 90, 125-136, https://doi.org/10.1016/j.marchem.2004.03.012, 2004.

Sachs, O., Sauter, E. J., Schlüter, M., Rutgers van der Loeff, M. M., Jerosch, K., and Holby, O.: Benthic organic carbon flux and oxygen penetration reflect different plankton provinces in the Southern Ocean, Deep-Sea Res. Pt. I, 56, 1319-1335, https://doi.org/10.1016/j.dsr.2009.02.003, 2009.

Schartup, A. T., Thackray, C. P., Qureshi, A., Dassuncao, C., Gillespie, K., Hanke, A., and Sunderland, E. M.: Climate change and overfishing increase neurotoxicant in marine predators, Nature, 572, 648-650, https://doi.org/10.1038/s41586-019-1468-9, 2019.

Schlesinger, W. H. and Bernhardt, E. S.: The Oceans, in: Biogeochemistry: an analysis of global change, 341-395, Academic Press, 2013.

Selin, N. E.: Global biogeochemical cycling of mercury: a review, Annu. Rev. Environ. Resour., 34, 43-63, https://doi.org/10.1146/annurev.environ.051308.084314, 2009.

Shanks, A. L. and Trent, J. D.: Marine snow: microscale nutrient patches 1, Limnol. Oceanogr., 24, 850-854, https://doi.org/10.4319/lo.1979.24.5.0850, 1979.

Smetacek, V., Klaas, C., Strass, V. H., Assmy, P., Montresor, M., Cisewski, B., Savoye, N., Webb, A., D’Ovidio, F., Arrieta, J. M., Bathmann, U., Bellerby, R., Berg, G. M., Croot, P., Gonzalez, S., Henjes, J., Herndl, G. J., Hoffmann, L. J., Leach, H., Losch, M., Mills, M. M., Neill, C., Peeken, I., Röttgers, R., Sachs, O., Sauter, E., Schmidt, M. M., Schwarz, J., Terbrüggen, A., and Wolf-Gladrow, D.: Deep carbon export from a Southern Ocean iron-fertilized diatom bloom, Nature, 487, 313-319, https://doi.org/10.1038/nature11229, 2012.
Soerensen, A. L., Mason, R., Balcom, P. H., and Sunderland, E. M.: Drivers of surface ocean mercury concentrations and air-sea exchange in the West Atlantic Ocean, Environ. Sci. Technol., 47, 7757-7765, https://doi.org/10.1021/es401354q, 2013.

Soerensen, A. L., Mason, R., Balcom, P. H., Jacob, D. J., Zhang, Y., Kuss, J., and Sunderland, E. M.: Elemental mercury concentrations and fluxes in the tropical atmosphere and Ocean, Environ. Sci. Technol., 48, 11312-11319, https://doi.org/10.1021/es503109p, 2014.

Soerensen, A. L., Schartup, A. T., Gustafsson, E., Gustafsson, B. G., Undeman, E., and Björn, E.: Eutrophication increases phytoplankton methylmercury concentrations in a coastal sea - A Baltic sea case study, Environ. Sci. Technol., 50, 11787-11796, https://doi.org/10.1021/acs.est.6b02717, 2016.

Sunderland, E. M. and Mason, R. P.: Human impacts on open ocean mercury concentrations, Global Biogeochem. Cy., 21, 115, https://doi.org/10.1029/2006GB002876, 2007.

Turner, J. T.: Zooplankton fecal pellets, marine snow, phytodetritus and the ocean's biological pump, Prog. Oceanogr., 130, 205-248, https://doi.org/10.1016/j.pocean.2014.08.005, 2015.

Vandal, G. M., Fitzgerald, W. F., Boutron, C. F., and Candelone, J.-P.: Variations in mercury deposition to Antarctica over the past 34000 years, Nature, 362, 621-623, https://doi.org/10.1038/362621a0, 1993.

Wang, J., Xie, Z., Wang, F., and Kang, H.: Gaseous elemental mercury in the marine boundary layer and air-sea flux in the Southern Ocean in austral summer, Sci. Total Environ., 603, 510-518, https://doi.org/10.1016/j.scitotenv.2017.06.120, 2017.

Whalin, L., Kim, E. H., and Mason, R.: Factors influencing the oxidation, reduction, methylation and demethylation of mercury species in coastal waters, Mar. Chem., 107, 278-294, https://doi.org/10.1016/j.marchem.2007.04.002, 2007.

Williams, G. D., Bindoff, N. L., Marsland, S. J., and Rintoul, S. R.: Formation and export of dense shelf water from the Adélie depression, East Antarctica, J. Geophys. Res.-Ocean., 113, 1-12, https://doi.org/10.1029/2007JC004346, 2008.

Yamane, M., Yokoyama, Y., Miyairi, Y., Suga, H., Matsuzaki, H., Dunbar, R. B., and Ohkouchi, N.: Compound-specific ${ }^{14} \mathrm{C}$ dating of IODP Expedition 318 core U1357A obtained off the Wilkes Land Coast, Antarctica, Radiocarbon, 56, 1009-1017, https://doi.org/10.2458/56.17773, 2014.

Zaferani, S., Pérez-rodríguez, M., and Biester, H.: Diatom ooze - A large marine mercury sink, Science, 361, 797-800, https://doi.org/10.1126/science.aat2735, 2018. 